Meta

Journal des traducteurs

Translators' Journal

\title{
The Present and Future of Audio Description and Subtitling for the Deaf and Hard of Hearing in Spain
}

\section{Francisco Utray, Ana María Pereira et Pilar Orero}

Volume 54, numéro 2, juin 2009

URI : https://id.erudit.org/iderudit/037679ar

DOI : https://doi.org/10.7202/037679ar

Aller au sommaire du numéro

Éditeur(s)

Les Presses de l'Université de Montréal

ISSN

0026-0452 (imprimé)

1492-1421 (numérique)

Découvrir la revue

Citer cet article

Utray, F., Pereira, A. M. \& Orero, P. (2009). The Present and Future of Audio Description and Subtitling for the Deaf and Hard of Hearing in Spain. Meta, 54(2), 248-263. https://doi.org/10.7202/037679ar
Résumé de l'article

Le présent article vise à faire le point sur les deux modes d'accessibilité aux médias les plus importants en Espagne : l'audiodescription et le sous-titrage pour sourds et malentendants. Il se reporte à l'origine de ces techniques, suit leur développement jusqu'à l'époque actuelle et examine les normes et les lois qui les régissent. Il propose une analyse des implications économiques et fonctionnelles de l'accessibilité aux médias, laquelle n'est pas gouvernée par les paramètres économiques conventionnels. Il aborde la détermination du profil des futurs professionnels du sous-titrage et de l'audiodescription en Espagne, qui sont formés dans le cadre de la traduction audiovisuelle. L'article se conclut par la proposition d'un éventail de mesures à prendre pour faire connaître ces services à un large public et pour atteindre une totale accessibilité, laquelle sera favorisée par le remplacement de la diffusion analogique par la radio et la télévision numériques. 


\title{
The Present and Future of Audio Description and Subtitling for the Deaf and Hard of Hearing in Spain
}

\author{
FRANCISCO UTRAY \\ Universidad Carlos III de Madrid, Madrid, Spain \\ futray@cesya.es
}

\author{
ANA MARÍA PEREIRA \\ Universidade de Vigo, Vigo, Spain \\ pereira@uvigo.es \\ PILAR ORERO \\ Universitat Autònoma de Barcelona, Barcelona, Spain \\ pilar.orero@uab.es
}

\section{RÉSUMÉ}

Le présent article vise à faire le point sur les deux modes d'accessibilité aux médias les plus importants en Espagne: l'audiodescription et le sous-titrage pour sourds et malentendants. Il se reporte à l'origine de ces techniques, suit leur développement jusqu'à l'époque actuelle et examine les normes et les lois qui les régissent. Il propose une analyse des implications économiques et fonctionnelles de l'accessibilité aux médias, laquelle n'est pas gouvernée par les paramètres économiques conventionnels. II aborde la détermination du profil des futurs professionnels du sous-titrage et de l'audiodescription en Espagne, qui sont formés dans le cadre de la traduction audiovisuelle. L'article se conclut par la proposition d'un éventail de mesures à prendre pour faire connaître ces services à un large public et pour atteindre une totale accessibilité, laquelle sera favorisée par le remplacement de la diffusion analogique par la radio et la télévision numériques.

\begin{abstract}
The aim of this article is to describe the state of the art in Spain of the two most popular media accessible modalities: audio description and subtitling for the deaf and hard of hearing. The article traces their origin and development up to the present time. It also examines standards and laws and analyses the economic and operative implications of media accessibility, which does not follow traditional economic parameters. The article aims to define the profile of future describers and subtitlers in Spain, who are currently being trained in the field of Audiovisual Translation. It concludes by proposing a wide variety of measures to be taken in order to reach full media accessibility and raise popular awareness of these services which are available now and will be increasingly so in the future with the change from analogous to digital broadcasting.
\end{abstract}

\section{MOTS-CLÉS/KEYWORDS}

audiodescription, doublage, sous-titrage pour sourds et malentendants, accessibilité des médias en Espagne, traduction audiovisuelle

audio description, dubbing, subtitling for deaf and hard of hearing, media accessibility in Spain, audiovisual translation 


\section{Introduction}

The profound transformation taking place in European media and broadcasting will benefit society in general and the growing number of people with special sensorial needs in particular. The aged population in Europe is growing fast and is predicted to increase steadily each year. ${ }^{1}$ Focused exclusively on Spain, this article gives an overview of the special services which will be available with digital media communication: Audio Description (AD) and Subtitles for the Deaf and Hard of Hearing $(\mathrm{SDHH})$. After an introduction defining these two modalities, the article describes their origins and development in Spain, as well as the standards and laws that regulate them and the corresponding economic and operative implications. The second part of the article studies the professional profile of those who are going to work in media accessibility, given the fact that they will be receiving university training in the area of Audiovisual Translation. We should remember that Spain is a country in which dubbing is very widely used and this will no doubt have direct implications in the voice artist market. The article concludes with an analysis of the numerous forms and icons that would contribute to the promotion of accessibility and to raising its profile within Spanish society.

\section{Definitions of $A D$ and SDHH in Spain}

In Spain, dubbing is widely used and this is one of the first considerations to be taken into account when dealing with media accessibility. Dubbing has direct implications on both the type of media accessibility and the professionals who will be in charge of it: describers and subtitlers.

The first definition of audio description in Spain is that offered by Navarrete, a describer who worked for the Spanish National Organisation of the Blind ONCE ${ }^{2}$ for many years and who in 1997 defined it as "the art of speaking in images" (1997: 71). In 2004, in Integración, the journal of the Spanish Cochlear Implant Association AICE, ${ }^{3}$ Vidal (2004: 30) wrote that audio description "simply tries to explain the action of a play, TV programme or film, etc. in such a way that the blind person can follow the development of the plot as well as possible." But it is the official Standard UNE where we find the most complete, up-to-date definition:

Audio description is an assistive service consisting of a set of techniques and abilities, whose main objective is to compensate for the lack of perception of the visual component in any audiovisual message, by providing suitable sound information which translates or explains, in such a way that the visually impaired perceive the message as a harmonious work which is as similar as possible to that which is perceived by the sighted. ${ }^{4}$ (AENOR 2005: 4)

On the other hand, subtitling for the deaf and hard of hearing (SDHH) could be defined as a modality of mode transaction (from oral to writing), which sometimes occurs between languages. It consists of displaying a written text on screen which offers a semantic account of what is happening during a given programme: not only what is said but also how it is said (emphasis, tone of voice, accents, foreign languages, different noises, etc.) and who says it. It includes contextual sounds such as environmental music and noises, and also the numerous discursive elements which appear on the screen (letters, words on posters, etc.) (Pereira 2005: 162). Unlike subtitles 
which include a change of language (interlingual) and are aimed at a public without hearing problems, subtitling in which there is no change of language (intralingual) or SDHH is articulated solely around two components: the subtitles and the image that accompanies them. These two elements, along with the nature and the reading pace of the receiver, define the characteristic traits of subtitling for people with hearing problems, who amount to a million in Spain (Pereira 2005: 162).

Although the Spanish Official Subtitling Standard UNE 153010 (AENOR 2003) does not offer a definition of SDHH, we find the following definition in the text drawn up by the Working Group named "Foro Técnico de la TV Digital" (2005: 5) of the Spanish Ministry of Industry: "Assistive service to communication that displays oral speeches, supra segmental information and sound effects on screen, which are present in any audiovisual work, through text and graphic elements."

The bill of the new audiovisual law (Anteproyecto de ley general audiovisual, MICyT 2005: 52), which will regulate SDHH and AD, gives the following definitions: "Subtitling is a written summary of dialogues, music and sound effects, displayed on screen simultaneously with the sounds emitted, and visible at the viewer's demand"7 and "Audio description is the independent sound track that can be selected by the viewer and which describes the characters, set design and key actions, in order to make the context of dialogues intelligible to blind people."

\section{Short history of AD and SDHH in Spain}

As far as audio description of recorded audiovisual material is concerned, Mateos Miguélez (2005) explains that it was the ONCE who first produced recorded audio description in 1993. The ONCE also had a system of free distribution amongst its members: "It started with four films in VHS and by 1997 had increased to 25 films per year" (ONCE 1997) (quoted in Mateos Miguélez 2005: 39). The ONCE gave audio description the name of Audesc. Hernández-Bartolomé and Mendiluce-Cabrera (2004) have described its origins, development and use in the cinema and even in film festivals.

TV broadcasting of closed commercial audio description (that is to say, only for those who want to listen) began on the Andalusian TV channel, Canal Sur, on $22^{\text {nd }}$ February of 1995. It was broadcast until the end of 1996 and 76 films were aired. The broadcast system was on radio and TV simultaneously. Those who wanted to listen to the AD version had to tune to Canal Sur Radio as well as the TV visual programme. Later on, in October 1997, a new scheme started under the name of Cine para Todos (Cinema for All), which offered SDHH along with AD, and it was on air until December 2001, after broadcasting 132 films. The weekly broadcast was first on Sundays and later on Saturdays. Subtitling was done through teletext and AD simultaneously on Canal Sur Radio. ${ }^{9}$

In 1999, the Catalan TV channel TV3 - the CCRTV's main channel ${ }^{10}$ - started to broadcast the TV series Plats Brut with Catalan AD. In this case the technical solution was the NICAM DUAL stereo system. The work of AD was done jointly with the ONCE. TV3, together with Catalan AD, has also broadcast the series Majoria Absoluta and L'un per l'altre.

Regarding the Spanish state-owned television organisation RTVE, ${ }^{11}$ Mateos Miguélez (2005: 34) comments that during the Parliamentary control session in 
Congress on $28^{\text {th }}$ May 2003, the Director General of RTVE said that from the $11^{\text {th }}$ of that same month the service of audio description would be available in the programme Cine de Oro and the service would be extended to other programmes, budget allowances permitting (RTVE 2003a). ${ }^{12}$

In 2002, RTVE, along with the publishing company BRB International and the ONCE, produced a cartoon series for children, Nicolás, in which the main character is a blind boy and in which audio description was taken into consideration right from the stage of production. The programme was broadcast with open audio description: that is to say, the audience had to hear the AD without having the choice of turning it off. Today RTVE is broadcasting some films with AD in the programme Cine de Barrio.

According to Mateos Miguélez (2005: 36), some AD programmes do exist but they are few and far between. We know, for instance, that the programme Guias Pilot had AD in the chapter entitled China Central (September $3^{\text {rd }}$ 2003) (RTVE 2003b), as did the film Las juergas del señorito (January $14^{\text {th }}$ 2004) (RTVE 2005).

Although Spanish cinemas are not equipped with the Dolby system which allows for closed $\mathrm{AD}$ or $\mathrm{SDHH}$, on given occasions films are audio described in special open shows, such as those organised by the Catalan Blind Association ACC. Live closed $\mathrm{AD}$ was also offered in the Liceo opera house in Barcelona (Matamala 2005 and Orero 2007a) during both the 2004-2005 and the 2005-2006 seasons. AD was offered by the ONCE and the ACC, whose describers are Albert Vidal and Llorenç Blasi respectively. ${ }^{13}$ Some theatres such as Teatre LLiure and TNC (Teatre Nacional de Catalunya) in Barcelona also offer audio description during many of their shows.

The first commercial DVD to have been audio described in Spain was the DVD of the TV3 series Plats Bruts (2003). Three years later Woody Allen's Match Point was the first DVD to be fully accessible in Spanish with subtitles for the deaf and hard of hearing, as well as a system which allows the sensorially impaired to navigate through its menu.

The first specific subtitles for the deaf and hard of hearing were broadcast in 1990 by the national Catalan TV corporation CCRTV ${ }^{14}$ and a few months later by the state Spanish TV TVE. ${ }^{15}$ Once the SDHH service was available the rest of the Spanish channels gradually started to offer it too. Pardina (1998 and 2000, in Méndez Brage 2002: 53-66) gives an overview of the Spanish panorama up to 2000. Pereira (2005) adds some new data for the following two years, and here we offer an update.

Telecinco, a private channel, started to offer SDHH towards the end of 1997 and progressively increased the total number of subtitled programmes from 700 in 1998 to 2,382 in 2007 . SDHH is offered every day at different times and during all types of programmes. Another private channel Antena 3 started its SDHH service in April 2000. At the beginning, it aimed at subtitling prime time. Today it broadcasts some 2,804 hours per year of in-house produced programmes, imports, game shows and films, etc. In Table 1 we can appreciate the growing number of SDHH hours from the years 1998 to 2007 in both state and regional channels. 
TABLE 1

Hours of SDHH per broadcaster/year in Spanish television

\begin{tabular}{|l|r|r|r|r|r|r|r|r|r|r|}
\cline { 2 - 11 } \multicolumn{1}{c|}{} & $\mathbf{1 9 9 8}$ & $\mathbf{1 9 9 9}$ & $\mathbf{2 0 0 0}$ & $\mathbf{2 0 0 1}$ & $\mathbf{2 0 0 2}$ & $\mathbf{2 0 0 3}$ & $\mathbf{2 0 0 4}$ & $\mathbf{2 0 0 5}$ & $\mathbf{2 0 0 6}$ & $\mathbf{2 0 0 7}$ \\
\hline RTVE & 569 & $\mathbf{7 8 2}$ & 982 & 1.296 & 1.630 & 3.148 & 5.028 & 6.869 & 8.492 & 8.201 \\
\hline TVC & 700 & 1.000 & 2.000 & 3.100 & 4.165 & 4.721 & 5.737 & 6.086 & 6.700 & 7.660 \\
\hline La Sexta & & & & & & & & & & 4.725 \\
\hline Canal Sur & 25 & 177 & 329 & 485 & 636 & 1.324 & 1.878 & 2.260 & 2.500 & 2.949 \\
\hline Antena 3 & & & 1.441 & 3.058 & 2.900 & 2.691 & 2.380 & 2.868 & 3.103 & 2.804 \\
\hline Telecinco & & 1.500 & 1.700 & 2.000 & 2.300 & 2.500 & 2.370 & 2.367 & 2.423 & 2.382 \\
\hline TVCM & & & & & & & & & & 2.066 \\
\hline RTVV & & & & & 467 & 1.185 & 1.408 & 1.410 & 1.544 & 1.580 \\
\hline Cuatro & & & & & & & & & & 1.488 \\
\hline Telemadrid & & & & & 1.135 & 1.358 & 1.354 & 1.373 & 1.225 & 942 \\
\hline ETB & & 380 & 390 & 396 & 400 & 405 & 470 & 494 & 630 & 666 \\
\hline
\end{tabular}

Source: Drafted by us from the Spanish Centre of Subtitling and Audio description (CESyA)

In Digital Pay TV, the Spanish version of the international channel Cartoon Network has been broadcasting some of its programmes with SDHH since April $1^{\text {st }}$ 2000. Disney Channel started to broadcast a selection of programmes with SDHH on November $2^{\text {nd }} 2003$ (Cinema Disney and series such as Men in Black and The Prince of Bel Air). In both cases the subtitles are inserted within the Vertical Blanking Interval (VBI) of the digital tape's video signal, thus providing perfect subtitle/image synchrony. The satellite operator Digital Plus has provided Disney Channel and Cartoon Network with the technological basis which allows them to broadcast digital subtitles that are accessible through STB remote control (Utray 2006).

In addition to the subtitles offered by the various TV channels, for the past fifteen years deaf people in Spain have had access to the project Subtitled Video Library (Videoteca subtitulada), which was started by the FIAPAS ${ }^{16}$ association and has been financed since 1993 by the Ministry of Work and Social Affairs. This project allows people with hearing problems to gain access to films in their own homes through domestic videos. The films are offered dubbed into Spanish and also have Spanish subtitles so whole families can enjoy watching them together. More than 300 films of all genres and for all ages have been distributed between the associations and centres for the deaf which have joined the project. It is estimated that some 200 associations have joined throughout Spain.

While it is increasingly common to find SDHH in commercial DVDs, audio description is still rare.

\section{Laws and Standards}

Recent developments in Spain show an increasing social awareness towards those with sensorial disabilities. The Spanish government drafted and passed two laws in June 2001 (BOE, July 10, 2001), La Ley de Fomento y Promoción de la Cinematografía y el Sector Audiovisual, and in December 2007 (BOE, December 29, 2007), Ley del cine, which offer grants for films with SDHH and AD.

In May 2002, those responsible for SDHH in the private channels Telecinco and Antena 3 asked the Government for a new and revised law regulating media acces- 
sibility and TV in particular, with grants for research in technical fields needing new development. The new audiovisual law Ley general audiovisual is now at a white paper stage. Its objectives are to merge current Standards and adapt them to the new technological and social context, and to regulate the laws on TV and radio in a general sense.

With this purpose arises the creation of an independent organization for the regulation of the sector: Consejo Estatal de los Medios Audiovisuales (National Council for the Audiovisual Media). One of its duties would be to check that operators comply with their obligations regarding accessibility.

With the Ley General del Audiovisual and the Consejo Estatal de los Medios Audiovisuales, Spain would have a comprehensive model for the introduction of accessibility into television, with a precise planning of the operators' commitments and an organ with the authority to ensure their fulfilment. The delay in the passing of these two draft bills means the slowing down of the process and the breach by the authorities of the set deadlines. The disagreement between the Government and the private television operators can be one of the reasons for this delay, as García Castillejo (2007) states in the following quotation:

Stopping this draft bill (Ley General del Audiovisual) and the one for the Ley de Creación del Consejo Estatal de Medios Audiovisuales (Law on the Establishment of the National Council for the Audiovisual Media) is the result of the pressure exerted by the TV broadcasters administered by private companies. These have set, among others, the obligations stated on them regarding subtitling, audio description and sign language insertion on TV program planning as the main reason to reject them, along the lines of our neighbouring countries' laws (García Castillejo 2007: 37).

It is therefore essential to remove these obstacles that hamper the enactment of the Ley General del Audiovisual for the regulation of the accessibility services and of the Ley de Creación del Consejo Estatal de Medios Audiovisuales in order to ensure the fulfilment of the obligations to be established.

The Standard UNE 153010 of September 2003, with the title Subtitling for deaf people and the hard of hearing. Subtitling through teletex $t^{17}$ published by the Spanish Association for Standardisation and Certification AENOR, ${ }^{18}$ has been established as a professional code of best practices. This Standard is the result of the many requests by deaf people asking for unified criteria for teletext SDHH within the different TV channels. A working group was formed by the numerous Spanish associations for the deaf (FIAPAS, ONCE, CNSE, AICE), TV channels, subtitling companies and subtitle professionals for the drafting process. ${ }^{19}$

Two years later, on January $26^{\text {th }} 2005$, the second media accessibility Standard was passed: the Standard UNE 153020 Audio description for visually impaired people. Requirements for audio description and for the production of audio guides. ${ }^{20}$ Its main beneficiaries are the numerous companies and professionals making audiovisual material accessible for those with sight impairments. It is also intended to serve as a reference for the creation of AD scripts (Orero 2005c).

In order to achieve consensus in the industry for the implementation of an accessible digital TV, the Technical Forum for Digital TV created a working group on accessibility in 2004. Its main objectives were to identify and assess the functionalities and needs of people with different disabilities, to identify standardization needs and to promote technological developments and research, in order to contribute to the 
development of such services. In October 2005 a document was published to support and act as a reference for the development of products, services and technical tools for accessibility for digital TV. Some of these services, like SDHH and AD, which had already been implemented in the analogue system, will find greater flexibility and higher quality systems (Foro Técnico de la TV Digital 2005: 6) with the new technology.

\section{Economic and operational implications of accessibility for broadcasting}

When analysing the cost of subtitling $100 \%$ of the programmes on a television channel, we have used the cost shown in the viability report of the "Spanish Centre of Subtitling and Audio description" of the Real Patronato de la Discapacidad (2005: 169) as a reference:

In general terms, subtitling costs in our country range between $4 €$ and $6 €$ per recorded minute, and $9 €$ for almost live (programmes broadcast with a slight delay). This would result in an average cost between $240 €$ and $360 €$ per subtitled hour, and $600 €$ in the case of expensive programmes.

If all programmes were to be newly subtitled, and provided that a year is made up of 8,760 hours, the necessary annual investment would exceed 2,500,000€ per broadcaster. Although this sum could be reduced by a creative organization of the efforts, together with an intelligent management of available resources and an efficient exchange of subtitled materials, we think that the cost is high for broadcasters and can pose a significant difficulty for the small channels that are bound to emerge from digital migration.

In the case of audio description, the estimated average cost per hour is around $800 €$, plus the cost of the transmission bandwidth for an audio channel. However, not all TV contents can be audio described. When the dialogue density does not allow for any silence, audio description cannot be provided. However, in programmes like news, debates or quizzes, a careful production can successfully make it possible for people with visual disability to follow the programme easily.

In the UK and the USA, the number of audio described hours required by the regulator is significantly below that required for subtitling. And, as we already said, forthcoming regulation in Spain will continue that trend.

Concerning the future implications of accessibility for the organization of broadcasters, we should first focus on the need to develop TV staff awareness. Training is the first action that should be carried out, so that each member of staff, regardless of his professional specialization, is aware of the sensorial diversity of the audience. The staff should also include members who specialize in assistive services management and production. Promoting the exchange of materials and an appropriate management of exploitation and intellectual property rights are also key elements for the rationalization of investments. At present, each broadcaster produces subtitling and audio description for its own broadcasting needs, but the exchanging of files between different operators is not dynamic enough. Movies to be shown in cinemas should be produced with accessibility services and should always be distributed with subtitles and audio descriptions in the following windows: DVD, PPV, Premium 
Channels, free TV and Catalogue. Unfortunately, this is not always the case, and the same content is often subtitled several times for the same market.

\section{The professional profile of the describer and subtitler in Spain}

At present what little commercial $\mathrm{AD}$ and $\mathrm{SDHH}$ there is for broadcasting and DVDs in Spain is done by either in-house translators - such as those in RTVE, Tele5, Antena 3, CCRTV - or by firms specializing in media postproduction. In both cases it can be safely said that the media accessibility market is not thriving in Spain. This situation could soon change with the implementation of the new media laws and the switch from analogue to digital TV. Soon there should be an important market with an increase in the number of media postproduction companies interested which will mean the creation of jobs for both describers and subtitlers. But what profile will these jobs have?

\subsection{Describer}

Up to now the little AD done in Spain at both commercial and association levels has been carried out from Spanish into Spanish: that is, from audiovisual material in Spanish - or Catalan - because it was home-produced or material that was already dubbed. But we must not forget that Spain imports much audiovisual material. It is also interesting to note that it is in the field of Translation Studies where media accessibility has rooted (Gambier 2003, 2004; Díaz Cintas 2005; Orero 2005a): a possible profile for describers will be that of the person who translates and describes. When considering the multiple and complex combinations of possible describer profiles in Spain (Orero 2006, 2007b), or any other country with widespread dubbing, we should bear in mind three variables, deriving from the basic concept of the describer as the person who creates the AD script:

- Will the describer also be the translator: describer/translator and describer

- Will the describer also be the subtitler: describer/subtitler and describer

- Will the intrasemiotic describer also be a subtitler SDHH: describer/subtitlerHH

These three possibilities could also be combined with one trait which has been traditionally an integral part of the profile of the describer: he also narrates the script. This is so for countries such as the UK (Hycks 2005), Spain (Navarrete 1997, 2005; Vidal 2004), US (Snyder 2005), Germany (Benecke 2004), etc. So many combinations can be juggled from the three variables plus narrator. These are early days to predict the possible outcome, and in Spain union agreements for dubbing actors should also be taken into consideration as these could have a direct effect on any of the possible profile combinations plus the narrator.

A describer has to work with two main media market characteristics: time and money. This means that the future describer will have to work at considerable speed and at a very competitive rate, which leads us to believe that the more tasks that can be accomplished by one person the faster - and cheaper - the work will be. In the case of working with foreign language material, it will mean that the translator for dubbing, or subtitler, will also create the description, since he already knows the product well and is acquainted with the many components present in any audiovisual translation: plot, characters, terminology, language style, etc. 


\subsection{Subtitler}

As with $\mathrm{AD}, \mathrm{SDHH}$ in Spain is a fundamentally intralinguistic modality. Broadcasters tend to make programmes with the language combination of Spanish/Spanish or Catalan/Catalan available with SDHH (TVE, Antena3, Tele5 and CCRTV). This may be so because they make their own productions accessible or because they are made from the Spanish/Catalan dubbed version. Therefore, nowadays we already have a solid profile of the intralinguistic subtitler $(\mathrm{SDHH})$, who also provides the subtitles for DVDs. Such is the case with the following films: Átame (Almodóvar 1990), Acción Mutante (De la Iglesia 1993), La lengua de las mariposas (Cuerda 1999), Lucía y el sexo (Médem 2001), Los lunes al sol (León 2002), La gran aventura de Mortadelo y Filemón (Fesser 2003), Mar adentro (Amenábar 2004), etc.

If, as expected with the passing of the new law, there is a steady increase in the number of hours with subtitles $(\mathrm{SDHH})$, broadcasters will have to either increase their workforce or give the work to freelance subtitlers or independent companies, as happens now with the subtitles and the dubbed version of any foreign film or programme.

The intralinguistic subtitler profile may exist along with another subtitler who will offer more services. While the former will only carry out subtitles within the same language, the latter will do subtitles involving language translation. If we can integrate both subtitling jobs together with the dubbing and $\mathrm{AD}$ in the same person, there is no doubt that there will be economic benefits for the client. If one person works with the translation of an audiovisual text he has first hand knowledge of its style, vocabulary, register, names of characters, plot, puns, jokes, cultural problems, etc., and he will therefore provide all the services faster. The client will end up with a higher quality product in less time and there will be a coherent relationship between all the versions: $\mathrm{AD}, \mathrm{SDHH}$, dubbing and subtitling. This holistic approach to the profile of the experts in media text transfer is also beneficial for translators.

Trainers of audiovisual translators in Spain have already noticed and studied all the aforementioned needs and benefits, and as we shall see now, they have already started to take some steps towards a more comprehensive training of experts in audiovisual transfer.

\subsection{Training of both $A D$ and $S D H H$}

In Spain media accessibility training (Orero 2005b) has been carried out by the few firms offering these services. In-house training has been provided according to their needs. In 2003 the Spanish Government published the $1^{\circ}$ Accessibility National Plan, ${ }^{21}$ where it established the guidelines for the implementation of Design for All from 2004 to 2012, and training was included (Orero 2005a). It said that it was up to universities to research and train in the many fields which form accessibility, given its multidisciplinary nature. It proposed the creation of some compulsory subjects at degree level to give the basics of accessibility in each field.

In other fields, such as architecture or design, accessibility has already been implemented in the academic curricula, but in Translation Studies, where media accessibility has been rooted, it is a recent training ground. Nevertheless, many universities have already taken up the challenge and have started developing courses 
and teaching materials. For undergraduates the Universitat Autònoma de Barcelona offers a course called "Media Accessibility" that is open to any student on the campus. The course provides the basic concepts and techniques on media accessibility: SDHH, $\mathrm{AD}$, web accessibility. Students will gain an insight into the many problems which disabled people face and also how they may be avoided to some extent with media accessibility. At postgraduate level, universities such as Granada, Seville, and Las Palmas offer postgraduate degrees in Subtitling for the Deaf and Audio description (Pereira and Lorenzo 2006). Within its MA in Audiovisual Translation - in both formats, face-to-face and online - the Universitat Autònoma de Barcelona started offering modules of SDHH, and it expanded to AD in 2006 and 2007. At the Universidade de Vigo, SDHH at undergraduate level is part of the final year of the degree in Translation in the course "Media Translation English/Spanish." At postgraduate level SDHH is also taught in the doctorate programme.

\section{The future of SDHH and AD: El Centro Español de Subtitulado y Audiodescripción}

In November 2005, the Framework Agreement for the creation of the Spanish Centre for Subtitling and Audio description (CESyA) was signed by the Real Patronato sobre Discapacidad, ${ }^{22}$ the CERMI ${ }^{23}$ and the Public University Carlos III of Madrid. This public institution is dedicated, among other things, to promoting $\mathrm{SDHH}$ and $\mathrm{AD}$ for disabled people and, in general, to encouraging all mechanisms that favour accessibility in the Spanish audiovisual arena. It helps all audiovisual accessibility stakeholders converge and serves as a link for dialogue. The associations that represent people with disabilities, the content production/distribution industry, the exhibitors/broadcasters, the consumer electronic industry and the regulator of the audiovisual and accessibility sectors can find in the CESyA a reference for the effective implementation of accessibility in audiovisual media (Ruiz 2005).

One of the main objectives of the CESyA is to create and manage a database service, with reviews of subtitled and audio described audiovisual works, which will be permanently updated and available to people involved in the audiovisual and accessibility arena. The documents, which will be entirely computerised, will be accessible on the Internet. The aim of this activity is to gather and reference all subtitled and audio described productions in order to encourage the exchange of materials and to boost the subtitling market, audio description and other assistive services (Ruiz, Enjuto et al. 2006).

Another priority is to make the audiovisual industry aware of the concept of universal accessibility and thus achieve awareness in the population as a whole. Caring for quality is an essential principle and public acknowledgment of a work well done can encourage industry and boost investment in Corporate Social Responsibility. Therefore, identifying the best quality products is not enough: we also need to ensure as much publicity about the subject as possible. It would be a great help to promote and advertise audiovisual accessibility services (what programmes are accessible and in which modality) in all media (radio, newspapers, television, Internet) so as to generate an accessibility culture among stakeholders and public opinion.

The Centre will also be the pioneer observatory of international research and standardisation in subtitling and audio description. 
Training is also part of the objectives of the Centre, and a series of national and international initiatives will be carried out too. There will be collaboration in the definition of training programmes in order to assure that the training of audiovisual accessibility professionals is standardised.

The creation of this centre is a necessary step in order to progress in implementing accessible audiovisual media in Spain and achieving equal opportunities and rights for people with visual or hearing disabilities.

\section{Conclusions}

As we have seen, there are a number of projects, at many institutional levels, aimed at making media accessibility a reality in Spain. In order to reach these objectives the coordinated work of all the implied parties will be necessary: the audiovisual industry, users associations, regulators and those responsible for training the new professionals. Who will be responsible and how to meet the extra costs to make media accessible are as yet unanswered problems. As it is, the audiovisual market is working with a very tight budget, hence concern for the future about the extra work. It is also true that if we analyse the number of potential users of these new formats, in economic terms it does not pay. That is, in traditional financial terms the possible revenue from the number of people using the new services (SDHH and $\mathrm{AD}$ ) is insignificant. No gain (in audience or commercials) will be made to justify the expense needed to make all media programmes fully accessible, and we have not talked here about signing programmes.

The associations of users aspire, obviously, to ensure that all contents are available to everybody. The audiovisual industry must face both the marginal costs and the technical and operative complexity involved in accessibility. Otherwise governments will have to think of possible schemes, such as tax reduction or exemption for the companies which fulfil a number of hours of accessible broadcasting, or awarding digital licences on the condition of accessible programming.

The first need we have identified is that the regulatory development of the audiovisual sector must incorporate these concepts explicitly, with introductory periods that the industry can assume. Control mechanisms and institutions capable of imposing sanctions so as to guarantee compliance will be necessary.

State-owned media should be the first to assume this responsibility and should serve as a motor and reference for the whole sector. The industry of production and distribution of contents must incorporate the necessary procedures to guarantee the availability of assistive services throughout the whole distribution chain (Utray 2005).

In order to develop media accessibility, five key factors have been identified: regulation, communication, training, production and signalling. Regarding regulation, it is fundamental that the Administration perform its duties and supervise the set procedures. A new public regulatory body should be set up in order to control and guard all the different standards. This public body, the State Audiovisual Council, should have the ability to issue sanctions and penalties and to foster self-regulation. It would grant broadcasting licenses to the companies that are committed to accessibility. It should also develop a fiscal policy encouraging investment in accessibility. Quality training is a key issue as it will provide well-qualified professionals who will 
then produce high quality subtitles and audio descriptions. We need to continue offering the currently available courses in SDHH and audio description as the translation faculties are already training professionals. It will be very important to ensure dynamic collaboration between universities and all the implied agents for the success of all these aspects. Regarding production, the way forward is to create a culture of quality production and to promote the exchange of accessible materials within the audiovisual industry. Sponsorship should also help increase the production of accessible TV and media for all.

And last but not least is the need to adopt a system of symbols which can identify accessible products clearly. It is a well known fact that people do not make full use of the accessible material available due to lack of information.

With the aim of informing viewers about the availability of the accessibility services, the reception equipment must highlight its existence: pick up the signaling of the transmission flow and present it with one symbol on the browsers and on the Electronic Programming Guides (EPG). The standardisation of these graphics is essential to homogeneously identify the accessible products (Orero, Pereira and Utray 2007). The ETSI Standard (2007), Access symbols for use with video content and ICT devices, suggests the use of some symbols for the accessibility services that don't match those used by the industry of the DTT receivers nor those the Spanish broadcasters use to indicate the presence of teletext subtitling on screen. The ETSI Standard symbols were defined using a methodology based on research with users (Mellors, Hodgkinson et al. 2006). On the other hand, in Spain, the AENOR Standard (2007) has standardised the use of a symbol to indicate the use of sign language in ICT devices that doesn't match the European either. Figure 2 shows the symbols suggested by the recent ETSI Standard and Figure 3 shows the symbols used in Spain for sign language and teletext subtitling.

\section{FIGURE 1}

Symbols used to indicate the existence of accessibility services (ETSI, 2007).

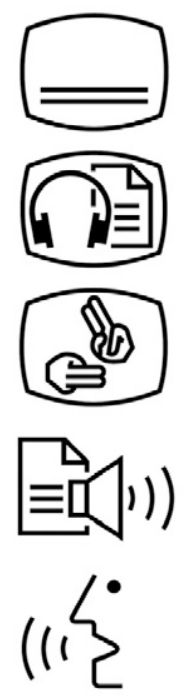

Subtitling

Audio description

Sign language

Speech output. Ability of a device to communicate to its users using spoken language.

Spoken commands. Ability of a device to accept and respond to spoken instructions from an user. 


\section{FIGURE 2}

Symbols used in Spain to indicate the existence of subtitling on analog television and sign language on the Internet.

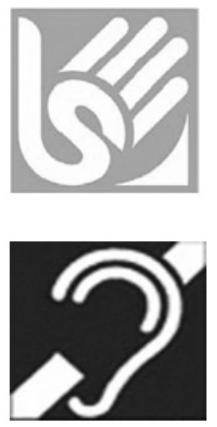

Symbol used to indicate the existence of sign language on the Internet (AENOR 2003b)

Symbol used by the Spanish broadcasters to indicate the existence of teletext subtitling

\section{NOTES}

1. Annual growth of the aged is estimated around or over 1\%. Source: Eurostat 2002.

2. Organización Nacional de Ciegos de España.

3. Asociación de Implantados Cocleares Españoles

4. "Servicio de apoyo a la comunicación que consiste en el conjunto de técnicas y habilidades aplicadas, con objeto de compensar la carencia de captación de la parte visual contenida en cualquier tipo de mensaje, suministrando una adecuada información sonora que la traduce o explica, de manera que el posible receptor discapacitado visual perciba dicho mensaje como un todo armónico y de la forma más parecida a como lo percibe una persona que ve." [our translation]

5. The Technical Forum for Digital TV is an initiative of the Ministry of Industry, Tourism and Trade to coordinate and promote the implementation of digital TV in Spain.

6. "Servicio de apoyo a la comunicación que muestra en pantalla, mediante texto y gráficos, los discursos orales, la información suprasegmental, y los efectos sonoros que se producen en cualquier obra audiovisual" [our translation].

7. "Se entiende por subtitulado, un resumen escrito de los diálogos, músicas y efectos de sonido, presentado en pantalla de forma simultánea al sonido, visible a voluntad del telespectador" [our translation].

8. "Se entiende por audiodescripción la banda de sonido independiente que puede ser seleccionada por el telespectador y que describe los personajes, los decorados y las acciones clave con objeto de hacer inteligible a personas ciegas el contexto en el que se desarrollan los diálogos" [our translation].

9. We would like to thank Fernando Mancha from the company Mundovisión in Seville (Spain) for all the information regarding audio description in Canal Sur.

10. The CCRTV (Corporació Catalana de Ràdio i Televisió), the Catalan state owned radio and TV corporation, has, among many other channels: TV3, Canal 33, 3/24, TV3 Internacional and Catalunya Ràdio.

11. RTVE (Radio Televisión Española) produces two main channels for analogue terrestrial distribution, an international signal and several digital channels.

12. "En el Control Parlamentario en el Congreso, el día 28 de mayo de 2003, el Director General de RTVE afirmaba que desde el día 11 de ese mismo mes se incluía el servicio de audiodescripción en las emisiones del programmea Cine de Oro y que irían ampliando de forma sucesiva esta opción a otros programmeas, según lo permitiese la disponibilidad presupuestaria (RTVE 2003a)" [our translation]

13. It is quite interesting to examine the information regarding the same opera $\mathrm{AD}$ by blind associations since each one offers a different $\mathrm{AD}$ of the same production.

14. This station, pioneer in SDHH in Spain, has notably increased the number of hours broadcasting with subtitles: from 400 in 1997 to more than 5,000 in 2004. Canal Sur broadcast subtitled in 2004 some 1950 hours, which gives a second place in the subtitled hours ranking - amongst autonomic 
channels. In third place we find the Valencian RTVV, and then Telemadrid and finally the Basque Euskal Televista.

15. This state public channel increased the number of hours of SDHH progressively: in 1997 it offered 400 hours, while in 2003 it has increased to 2,500. In 2004 they have subtitled over 5,000 hours in the three stations TVE1, La 2 and Canal Internacional (González Somovilla 2004: 31). The subtitling service of this public channel has created its own style manual based on its own experience and also BBC and RAI.

16. FIAPAS (Confederación española de padres y amigos de los sordos) is one of the main associations of deaf people in Spain.

17. Subtitulado para personas sordas y personas con discapacidad auditiva. Subtitulado a través del teletexto.

18. Asociación Española de Estandarización y Certificación.

19. A critical analysis of this Standard is provided in Pereira and Lorenzo (2005).

20. Audiodescripción para personas con discapacidad visual. Requisitos para la audiodescripción y elaboración de audioguías

21. I PLAN NACIONAL DE ACCESIBILIDAD 2004-2012 Por un nuevo paradigma, el Diseño para Todos, hacia la plena igualdad de oportunidades. Approved by the Government on July $25^{\text {th }} 2003$.

22. The Real Patronato sobre Discapacidad is an autonomous organization of the General State Administration dependent on the Ministry for Work and Social Affairs and, among other things, it promotes the prevention of deficiencies, rehabilitation and social inclusion and equal opportunities.

23. CERMI (Spanish Confederation of representatives of the disabled) is the representative organization that unites all Spanish Associations of People with disabilities.

\section{REFERENCES}

AENOR (2003): Standard UNE 153010: Subtitulado para personas sordas y personas con discapacidad auditiva. Subtitulado a través del teletexto. Madrid: AENOR.

AENOR (2005): Standard UNE 153020: Audiodescripción para personas con discapacidad visual. Requisitos para la audiodescripción y elaboración de audioguías. Madrid: AENOR.

AENOR (2007): Requisitos para el uso de la lengua de signos española en redes informáticas. PNE 139804. Madrid: AENOR.

BenECKe, Bernd (2004): Audio-description. Meta. 49(1):78-80.

Díaz Cintas, Jorge (2005): Audiovisual translation today. A question of accessibility for all. Translating Today. 4:3-5.

ETSI (2007): ETSI ES 202432 V. 0.0.2 Access symbols for use with video content and ICT devices. Sophia Antipolis (France): European Telecommunications Standards Institute (ETSI).

Foro Técnico de la TVD (2005): Accesibilidad en Televisión Digital para personas con discapacidad. Documento elaborado por Grupo de Trabajo 5 sobre Accesibilidad del Foro Técnico de la televisión digital. Madrid. Octubre 2005.

GAmbIER, Yves (2003): Introduction. The Translator. 9(2):171-189.

GAMBIER, Yves (2004): La traduction audiovisuelle: un genre en expansion. Meta. 49(1):1-11.

García Castillejo, Ángel (2007): El inacabado marco jurídico para la accesibilidad a la televisión digital. Accesibilidad a los medios de comunicación para personas con discapacidad. Amadis 06. Madrid: Real Patronato sobre Discapacidad, 25-34.

González Somovilla, Miguel (2004): Informe Anual sobre el Cumplimiento de la función de Servicio Público en 2004. Dirección Gerencia de Comunicación y Relaciones Institucionales de RTVE. Consultado el 28 de enero de 2009, <http:/www.rtve.es/files/63-79-FICHERO/ Informe_RTVE2004.pdf>.

Hernández-Bartolomé, Ana and Mendiluce-Cabrera, Gustavo (2004): Audesc: Translating Images into Words for Spanish Visually Impaired People. Meta. 49(2):264-277.

Нүкs, Veronika (2005): Audio Description and Translation. Two related but different skills. Translating Today. 4:6-8.

Matamala, Anna (2005): Live Audio Description in Catalonia. Translating Today. 4:9-11. 
Mateos MiguéLez, Berta (2005): Audiodescripción: estudio y análisis a través de un fragmento de la película Shrek (Unpublished dissertation). Universidade de Vigo: Facultade de Filoloxía e Tradución.

Mellors, Walter J., Hodgkinson, Richard and Miller, Clive (2006): Access symbols for use with video content and ICT devices. $20^{\text {th }}$ International Symposium on human factors in telecommunication. Sophia Antipolis (France). Consultado el 28 de enero de 2009, <http:// www.hft.org/HFT06/paper06/09_Mellors.pdf>.

MÉNDez Brage, Belén (2002): El subtitulado para sordos (Unpublished dissertation). Vigo: Facultade de Filoloxía e Traducción.

MICyT (2005): Borrador de anteproyecto de Ley General Audiovisual.

Navarrete, Fernando (1997): Sistema AUDESC: el arte de hablar en imágenes. Integración. 23:70-75.

Navarrete, Fernando (2005): Sistema Audesc: el fin de los Susurros. Seminario sobre medios de comunicación sin Barreras. Consultado el 28 de enero de 2009, <http://www.uch.ceu. es/sinbarreras/textos/jnavarrete.htm>.

ONCE (1997): Programmea Audesc. Informe de la Dirección de Cultura de la ONCE.

ONCE (2003): Servicio de asesoramiento y orientación personal hacia el ocio y el tiempo libre. Consultado el 28 de enero de 2009, <http://www.once.es/home.cfm?id=257\&nivel=4\& orden $=4>$.

Orero, Pilar (2005a): La inclusión de la accesibilidad en comunicación audiovisual dentro de los estudios de traducción audiovisual. Quaderns de Traducció. 12:173-185.

Orero, Pilar (2005b): Teaching Audiovisual Accessibility. Translating Today. 4:12-15.

Orero, Pilar (2005c): Audio Description: Professional Recognition, Practice and Standards in Spain. Translation Watch Quarterly. 1:7-18.

Orero, Pilar (2006): Algunas consideraciones sobre la audiodescripción comercial en España. In: Ricardo Perez-Amat y Álvaro Pérez-Ugena, eds. Algunas consideraciones sobre la audiodescripción comercial. Sociedad, integración y televisión en España. Madrid: Laberinto, 277-292.

Orero, Pilar (2007a): Audiosubtitling: A Possible Solution for Opera Accessibility in Catalonia. In: Eliana P. C. Franco y Vera Santiago Araújo, eds. TradTerm (Revista do Centro Interdepartamental de Tradução e Terminologia, 13:135-149.

Orero, Pilar (2007b): ¿Quién hará la audiodescripción comercial en España? El futuro perfil del descriptor. In: Catalina Jiménez, ed. Traducción y accesibilidad. Subtitulación para Sordos y audiodescripción para ciegos: nuevas modalidades de Traducción Audiovisual. Frankfurt: Peter Lang, 111-120.

Orero, Pilar, Pereira, Ana María and Utray, Francisco (2007): Visión histórica de la accesibilidad en los medios en España. Trans. Revista de Traductología. 11:31-44.

Pardina I Mundó, Joaquím (1998): El futuro de la subtitulación para personas sordas o con pérdidas auditivas. Consultado el 28 de enero de 2009, <http://www.terra.es/personal6/ 932108627/Articulos/arti3-C.htm>.

Pardina I Mundó, Joaquím (2000): Estudio sobre el Servicio Audiovisual de Subtitulación para personas sordas o con pérdidas auditivas en el mercado televisivo español. Dirección Audiovisual de la CMT.

Pereira, Ana María (2005): El subtitulado para sordos: estado de la cuestión en España. Quaderns. Revista de traducción. 12: 161-172.

Pereira, Ana María y Lorenzo, Lourdes (2005): Evaluamos la norma UNE 153010: Subtitulado para personas sordas y personas con discapacidad auditiva. Subtitulado a través del teletexto. Puentes. 6: 21-26.

Pereira, Ana María y Lorenzo, Lourdes (2006): La investigación y formación en accesibilidad dentro del ámbito de la traducción audiovisual. In: Consuelo Gonzalo García y Pollux HeRnúÑEz, eds. CORCILLVM. Estudios de traducción, lingüística y filología dedicados a Valentín García Yebra. Madrid: Arco Libros, 649-658. 
Real Patronato de la Discapacidad (2005): Estudio de viabilidad del Centro Español de Subtitulado (FASE I). Consultado el 28 de enero de 2009, <http://www.rpd.es/cesya.html $>$.

RTVE (2003a): Control Parlamentario de RTVE, 28 mayo 2003. Consultado el 28 de enero de 2009, <http://www.aideka.tv/Serviciosinformativos/Diario\%20de\%20sesiones\%20285-03.pdf $>$.

RTVE (2003b): Programmeación. 3 septiembre. Consultado el 28 de enero de 2009, <http://www. rtve.es/tve/programmeo/avan2/tv2s0309.htm>.

RTVE (2005): Programmeación. 14 de enero. Consultado el 28 de enero de 2009, <http://www. rtve.es/tve/programmeo/avan2/tv2s1401.htm>.

Ruiz, Belén (2005): Accesibilidad a las Nuevas Tecnologías. Congreso Nacional de Discapacidad "Accesibilidad Universal en el Siglo XXI." Ponferrada (León), November 30, 2005. Consultado el 28 de enero de 2009, <http://www.rpd.es/publicaciones/accesibilidad_universal.html>.

Ruiz, Belén, Enjuto, Natividad, Sánchez, Pena et al. (2006): El centro Español de Subtitulado y Audiodescripción: estrategias para fomentar la accesibilidad a los medios audiovisuales en España. IV Congreso Iberdiscap: Tecnologías de Apoyo para la Discapacidad. Vitoria, Brasil. 20-22 de febrero de 2006.

Snyder, Joel (2005): Audio Description. The Visual Made Verbal Across Arts Disciplines - Across the Globe. Translating Today. 4:15-17.

Utray, Francisco (2005): Trends and measures to facilitate digital TV accessibility for disabled people in Spain. Paper presented at Media for All. International Conference. Barcelona, Universitat Autònoma de Barcelona.

Utray, Francisco (2006): Situación actual de la accesibilidad a la TV en España. IV Congreso Iberdiscap: Tecnologías de Apoyo para la Discapacidad. Vitoria, Brasil. 20-22 de febrero de 2006.

VIDAL, Albert (2004): La audiodescripción: una herramienta de ayuda para los ciegos. Integración. Revista de la Asociación de Implantados Cocleares. 32:30-31. 